\title{
Widening and deepening? Recent advances in European Integration History
}

\author{
Kiran Klaus Patel
}

Published online: 17 June 2019

(C) The Author(s) 2019

\begin{abstract}
This review article assesses recent advances in European integration history. It demonstrates that in recent years, research angles have multiplied and thus complicated our understanding of the historical phenomenon at stake. It also argues that it is for this very reason that the field has become more relevant for broader questions of contemporary historical research. While presenting individual studies and tendencies within the field, this review article therefore understands itself to be a plea to forge stronger links between various areas of research.
\end{abstract}

Keywords European Integration · European Community · European Union · Contemporary History

By many standards, European integration history is a relatively young field of research. ${ }^{1}$ This mainly reflects the object of enquiry, which can be seen as a comparably recent phenomenon, at least when defined as the close and structured cooperation between equal and sovereign states in Europe based on shared rules and institutions to which they transfer some of their powers. Rigorous research on these Western European, post-45 developments commenced in the 1960s, mostly conducted by legal scholars and political scientists. At the time, historians interested in the topic mainly focused on the prehistory of pro-European thinking, often in search of a useful past for federalist ideas in their own times. Things only started to change during

\footnotetext{
1 Most studies published after 2018 could not be considered for this text. I have tried avoiding references to my own work. Where it (or projects in which I have been involved closely, e.g., as $\mathrm{PhD}$ thesis supervisor and in an advisory or similar capacity) is referred to, it is only cited, not reviewed.
}

Prof. Dr. K. Klaus Patel $(\bowtie)$

Maastricht, The Netherlands

E-Mail: k.patel@maastrichtuniversity.nl 
the 1970s and even more during the 1980s, when more and more archival material on the 1940s and 1950s became available. So while comparably young, European integration historiography can now look back on some 40 years of research.

How did the field develop over this span of time? During its first two to three decades, diplomatic history dominated the field, followed by economic interpretations. The main research foci were the political negotiations that drove the integration process, along with the economic factors that undergirded them. This interest in motives, driving forces, debates, and their institutional outcome defined most of the empirical work, but also the (comparably few) conceptual and theoretical deliberations. This certainly holds true for the most influential contribution of the latter kind, by Alan S. Milward, who famously argued that the integration process is best summarized as the "European rescue of the nation-state": for him, the European Community (EC) as the predecessor of today's European Union (EU) was not the anti-thesis of the nation-state. Quite the contrary: integration was an integral part and a vital instrument "of the reassertion of the nation-state as an organizational concept."2

While the questions and arguments raised by Milward and other first-generation scholars have remained important, research has taken several new directions over the course of the past 10 to 15 years. This implied a move beyond both the federalist perspective, with its proclivity to normative overdrive, as well as beyond the statecentric approach of the Milwardian brand, according to which the interests of the major nation-states controlled European integration. Supranational actors, most notably the European Commission, but also the European Parliament and the European Court of Justice, have been factored in. Conceptually, the cultural and transnational turns have rubbed off on the field, adding new angles, for instance on representation, identity, and the role of non-state actors. With regard to research questions, the concentration on "how the European Community came about," to quote Milward again, ${ }^{3}$ has given way to more diverse perspectives with researchers now also assessing the impact of integration on European societies, among other issues. Finally, the field has witnessed a self-reflexive turn of sorts, with historiographical surveys mushrooming and the question of narratives and conceptualization sparking new debates. All these developments, of which this article takes stock, are signs that the field has reached a new level of maturity. ${ }^{4}$

Widening and deepening: one might be tempted to describe the main historiographical trends in this field in such terms, given how approaches and methodologies have expanded and considering that our knowledge has become ever more refined. This would follow the interpretative pattern which the protagonists of European integration have produced about the process and which has impacted public and

\footnotetext{
2 Milward, Alan S.: The European Rescue of the Nation-State, Routledge, London/New York ${ }^{2}$ 2000, p. 3. ${ }^{3}$ Ibidem, p. VIII.

${ }^{4}$ This debate arguably commenced with Mark Gilbert's reflection on the Whig narrative underlying much of EU history writing: Gilbert, Mark: Narrating the Process: Questioning the Progressive Story of European Integration, in: Journal of Common Market Studies 46 (2008), pp. 641-662. On EU historiography see, for example, Kaiser, Wolfram/Varsori, Antonio (eds.): European Union History: Themes and Debates, Routledge, Houndmills 2010; Warlouzet, Laurent: The Interdisciplinary Challenge in European Integration History, in: Journal of Contemporary History 49 (2014), pp. 837-845.
} 
academic debates for a long time. According to such views, integration developed in fits and starts; the ultimate direction, however, was towards ever further rounds of enlargement and an ever-closer union between member states and their societies. Politically, such a view has lost support and credibility over the past decade. Translating this language to the historiographical tier would come at a high price, too. Some of the important trends in recent years lead in very different directions, including a strand of research that de-centers the EU's predecessors as the exclusive or even just the most eminent arena of European cooperation. All in all, the multiplication of research angles has complicated the story and qualified the logic of "wider and deeper" with its teleological overtones. It is also for this very reason that the field has become more relevant for broader questions of contemporary historical research, as this review article argues. Hence the question mark after this article's main title; it is for the same reason that the term "advances" in the subtitle should be taken with a pinch of irony.

While the entry price into this historiographical field is comparably high-many studies are based on multi-national research entailing substantial linguistic, logistical, financial, and narrative challenges-it is now a highly productive research domain generating certain insights which deserve wider reception. Hence, it is not just the challenges of the EU in our own times that make its past relevant; the findings of many of the books and articles in the field also speak to broader debates in contemporary history.

Still, these links have remained comparably weak to this day. A recent example for the tendency in the discipline to ignore European integration history is an otherwise very perceptive research survey by Jan Eckel on the history of international politics between the 1940s and the 1990s. Discussing a plethora of studies on all kinds of issues, research on European integration history remains largely beyond his radar, even if in his conclusions, he stresses the need to know more about the role of Europe-and European integration —in world politics. ${ }^{5}$ Eckel's article is a symptom of a wider trend.

Beyond presenting individual studies and tendencies within the field, this review article therefore understands itself to be a plea to forge stronger links between various fields of research. In doing so, it cannot claim to offer a complete overview of recent publications. Even if European integration history has remained a comparably small (though highly internationalized and, at least until recently, emphatically multilingual) field of enquiry, publications abound. I will therefore provide a succinct survey of major trends and highlight a few studies epitomizing the various currents. More precisely, the following proceeds in five steps: it firstly discusses new research that deals with the organizational and institutional history of European integration, including its legal dynamics. It then presents publications on various policy fields associated with European integration. Thirdly, it examines several studies on public perceptions of and support for European integration as well as images of Europe

\footnotetext{
5 Eckel, Jan: Vielschichtiger Konflikt und transnationale Steuerung. Zur Neuinterpretation der Geschichte internationaler Politik zwischen den 1940er- und den 1990er-Jahren, in: Archiv für Sozialgeschichte 57 (2017), pp. 497-535, here 534.
} 
more broadly. A fourth section deals with the EC/EU's engagement with the wider world. The conclusion summarizes the general findings.

\section{The making of a transnational polity: European institutions, member states, and the role of law}

In comparison to earlier decades, the relative weight of research dealing with the institutional history of European integration has diminished. This partly reflects the rise of approaches beyond diplomatic history; partly, it echoes the growing complexity of the process under study. Over time, the number of policy fields and issues affected by European politics and policies has increased. Hence, it has become more difficult to provide a comprehensive picture of the overall organizational development. Many new publications analyze the developments in specific policy domains, an approach dealt with in this review article's second section.

Before dealing with more specialized research on the EC/EU as a transnational polity, some of the recent synthesis shall be presented. Wilfried Loth, one of the foremost experts in the field who has contributed to it since its inception, has recently published a survey of EU history from the early postwar period until today. It mainly focuses on the diplomatic negotiations in the process of Building Europe (as in the title of the English version, which came out in 2015; the German original was published one year earlier). With this approach, Loth's book is an indispensable survey for years to come, synthesizing his work and that of others on the topic over the past decades. Some might miss a global perspective on EU history, as will be discussed below (Sect. "The Cold War and beyond: integration in a global world"), or an analysis of the cultural dimension of integration. Those issues remain beyond the scope of this book, which is steeped in diplomatic history. ${ }^{6}$

From the other end of the scale of seniority comes Luuk van Middelaar's The Passage to Europe. The book, originating in a $\mathrm{PhD}$ thesis at Amsterdam University, has nonetheless turned into a smashing success. It has been translated into almost a dozen languages and won several distinguished prizes; undoubtedly, it has been the most widely received account of European integration history over the past decade. The book is brilliantly written and impresses by transcending the usual focus on national interests, negotiations, and nitty-gritty steps of institution-building. Middelaar imports the categories through which he analyzes European integration history from political theory. Many of his findings are highly inspiring, and he deserves greatest respect for the audacity with which he transcends well-established narratives and ways of structuring such a book. Having said that, Middelaar often ignores the detailed and archive-based research in the field; he tends to essentialize certain traits and characteristics in European integration history and deals with them rather ahistorically. In some parts, his book reads more like a politico-philosophical manifesto than an empirical analysis. No wonder that Machiavelli, Madison, and Hegel have more entries in the index than many post-45 politicians (let alone other

\footnotetext{
${ }^{6}$ Loth, Wilfried: Building Europe: A History of European Unification, De Gruyter, Berlin 2015 (German original: Europas Einigung. Eine unvollendete Geschichte, Campus, Frankfurt a. M/New York 2014).
} 
contemporaries) and that he does not shy away from political statements. This also helps to explain the author's brilliant career in Brussels and beyond since his book came out. Historians in the field are well advised to read Middelaar's book very carefully - to draw inspiration from it, while also viewing it with critical distance. ${ }^{7}$

Measured by Middelaar's yardstick, The Unfinished History of European Integration has a much more modest aim. Co-authored by a group of scholars based at various Dutch universities, and first published in Dutch and now also in several other languages, it provides a survey in form of a handbook for a broad audience. The book is very accessible and short enough to work as an introduction to the topic. Unfortunately, the seven strategic predicaments introduced at the book's beginning (which are centered around the two following questions: who shaped Europe? And how should a united Europe look?) do little to guide the reader through it. Moreover, the various parts are of different quality, and some smaller inaccuracies and imbalances have crept in. ${ }^{8}$ Meanwhile, two volumes from the European Union Liaison Committee of Historians, an international network of scholars working in this field, ${ }^{9}$ have pushed the boundaries of our knowledge further into the 1970s and early 1980s: One, edited by Johnny Laursen, mostly deals with internal dynamics in the EC and its institutions at the time; the other, edited by Claudia Hiepel, has a stronger focus on how the communities reacted to global challenges during this period. ${ }^{10}$ While particularly the latter offers many fresh perspectives, they both debunk the myth of an older literature according to which this period was a "dark age" of European integration. ${ }^{11}$

In the more specialized literature on institutions and organizational history, publications on the European Commission deserve to be mentioned first. For quite some time now, this institution has been encouraging research on its own past, leading to a series on the "history and memory of an institution" which the Commission lavishly sponsors and publishes in several languages. A first volume, covering the years from 1958 to 1972 , contained many pieces that were very short and not sufficiently informed by the state of the art to serve as valuable scholarly contributions; the book was more about "memory" (with a tendency to hagiography) than "history."

\footnotetext{
7 Middelaar, Luuk van: The Passage to Europe: How a Continent Became a Union, Yale UP, New Haven, CT/London 2013 (Dutch original: De passage naar Europa. Geschiedenis van een begin, Historische Uitgeverij, Groningen 2009).

8 Meurs, Wim van/Bruin, Robin de/Grift, Liesbeth van de/Hoetink, Carla/Leeuwen, Karin van/Reijnen, Carlos: The Unfinished History of European Integration, Amsterdam UP, Amsterdam 2018 (Dutch original: Europa in alle staten. Zestig jaar geschiedenis van de Europese integratie, Uitgeverij Vantilt, Nijmegen 2013).

9 On this committee, see Varsori, Antonio: From Normative Impetus to Professionalization: Origins and Operation of Research Networks, in: Kaiser/Varsori, European Union History, pp. 6-25. I would like to make explicit that I am a member of the aforementioned group. Hence, references to these volumes will remain short.

${ }^{10}$ Laursen, Johnny (ed.): The Institutions and Dynamics of the European Community, 1973-83, Nomos, Baden-Baden 2014; Hiepel, Claudia (ed.): Europe in a Globalising World: Global Challenges and European Responses in the "Long" 1970s, Nomos, Baden-Baden 2014.

11 So the formulation in Keohane, Robert O./Hoffmann, Stanley: Institutional Change in Europe in the 1980s, in: idem (eds.): The New European Community: Decision-making and Institutional Change, Westview Press, Boulder, CO 1991, pp. 1-39, here p. 8.
} 
The follow-up volume on 1973 to 1986 has much more academic value and is an indispensable reference for the Commission's work during the period under study. ${ }^{12}$

Equally importantly, such research is closely connected to work taking a biographical approach. Some of these publications are spin-off projects of the history of the European Commission, most notably Piers Ludlow's study of British politician Roy Jenkins' role as Commission President during the 1970s. Among its other values (such as shedding new light on UK-EC relations at the time), Ludlow's work underscores the significance of access to private papers of the relevant actors. While the official paper trail sometimes does more to hide than to reveal internal deliberations and the dynamics of European integration, such privately documented sources are often indispensable to arrive at new findings. ${ }^{13}$ The same holds true for a recent collection on German Christian Democrats and their role in European integration from Adenauer to Merkel, where many chapters draw on the collections in the Archive for Christian Democratic Policy in Sankt Augustin near Bonn. ${ }^{14}$ The life of possibly the most important actor during the first postwar decades of European integration, Jean Monnet, has recently been re-examined in a biography by Klaus Schwabe. Schwabe demonstrates the formative experience of this French politician during World War I and as Deputy General Secretary in the League of Nations, without which his ideas and his networks, and hence his role in post-45 European integration, cannot be understood. While largely building on existing studies, it might come as a surprise that this is the first biography on Monnet ever published in German. ${ }^{15}$ All in all, biographical research has been somewhat on the rise since the beginning of the decade, with biographical monographs on commissioners such as Sicco Mansholt, and compilations of biographical essays. ${ }^{16}$

Besides this focus on actors and institutions at the European level, it is almost surprising how few studies have recently been published on the role of specific member states in the process of European integration, particularly since this approach dominated the first decades of historiography. Ironically, the first archivebased synthesis of West Germany's role in the EC for the period until the mid1960s was penned by an Italian. Gabriele D’Ottavio's succinct analysis highlights

\footnotetext{
12 European Commission (ed.): The European Commission: History and Memories of an Institution, 1958-1972, Publications Office of the EU, Luxembourg 2007; European Commission (ed.): The European Commission: History and Memories of an Institution, 1973-1986, Publications Office of the EU, Luxembourg 2014. The third volume will appear in May 2019: European Commission (ed.): The European Commission: History and Memories of an Institution, 1986-2000, Luxembourg 2019.

13 Ludlow, N. Piers: Roy Jenkins and the European Commission Presidency, 1976-1980: At the Heart of Europe, Palgrave Macmillan, Basingstoke/New York 2016.

14 Küsters, Hanns Jürgen: Deutsche Europapolitik Christlicher Demokraten. Von Konrad Adenauer bis Angela Merkel (1945-2013), Droste, Düsseldorf 2013.

15 Schwabe, Klaus: Jean Monnet. Frankreich, die Deutschen und die Einigung Europas, Nomos, BadenBaden 2016.

16 See, e.g., Merriënboer, Johan van: Sicco Mansholt: A Biography, Lang, Brussels 2011; Knudsen, AnnChristina L./Gram-Skjoldager, Karen: Living Political Biography: Narrating 20th Century European Lives, Aarhus UP, Aarhus 2012. Based on a conference at the Max Planck Institute for European Legal History, a book on the key biographies in the legal history of European union, 1950-1993, to be edited by Philip Bajon and Stefan Vogenauer, is currently being prepared [https://www.rg.mpg.de/1467945/event18-06-21key-biographies; last accessed 20 March 2019].
} 
the main debates and diplomatic negotiations and offers a good introduction to the topic. ${ }^{17}$ A recent monograph by Robin de Bruin on the Netherlands covers basically the same period but concentrates less on diplomatic history than on the reaction of Dutch parties to European integration and-very interestingly_on how Dutch party politics became more flexible due to their exposure to European integration. De Bruin has a sophisticated argument on how Dutch perceptions of Europe's future confirmed and strengthened Dutch national compromise politics, a point relevant beyond the Dutch case. ${ }^{18}$ Benjamin Grob-Fitzgibbon widens the canvas even further in his discussion of the role of the United Kingdom in European integration. He claims that the experience of the decline of empire and of global influence fueled the rise of British Euroscepticism. Grob-Fitzgibbon links European integration to the history of empire, and he stresses that in postwar Britain, European and imperial identities went hand in hand. The claim is fascinating, and research with a similar argument will be referred to again in the section "The Cold War and beyond: integration in a global world." It is therefore a particular pity that Grob-Fitzgibbon sometimes loses his focus in a general description of the UK's engagement with European integration-a topic many others have covered already. Conceptually, his book is rather traditional, highlighting the role of the top shakers and movers. Still, this is not just a highly readable, but also a worthwhile attempt to link the history of European integration to broader and hitherto compartmentalized historiographical concerns such as the histories of empire and decolonization. ${ }^{19}$ Published weeks before the 2016 Brexit referendum, developments since have only added urgency to its approach.

While these studies mainly concern themselves with political negotiations and their contribution to creating a supranational polity at the European level, another approach has proven to be extremely productive and innovative: the elucidation of institutional developments through the lens of law. Long ignored due to the preponderance of diplomatic and economic history, things only started to change over the past ten years. Even more than for other questions, this debate has a strong interdisciplinary thrust-obviously in cooperation with legal scholars, but also with a particularly interesting strand of political sociology. The latter takes its cue from the work of Pierre Bourdieu and applies some of his theories to (the history of) European integration; not surprisingly, this approach has strong roots in French academic traditions.

Antoine Vauchez's habilitation thesis, published in French in 2013 and in English in 2015, is an excellent example of this approach: his main ambition is to explain how law came to play a decisive role in building the EU polity, and in order to do so, he analyzes transnational groups of policy entrepreneurs who have pushed for law

17 D'Ottavio, Gabriele: Europa mit den Deutschen. Die Bundesrepublik und die europäische Integration (1949-1966), Duncker \& Humblot, Berlin 2016 (Italian Original: L'Europa die tedeschi. La Repubblica Federale Tedesca e l'integrazione europea, 1949-1966, Il Mulino, Bologna 2012).

18 Bruin, Robin de: Elastisch Europa. De integratie van Europa en de Nederlandse politiek, 1947-1968, Wereldbibliotheek, Amsterdam 2014.

19 Grob-Fitzgibbon, Benjamin: Continental Drift: Britain and Europe from the End of Empire to the Rise of Euroscepticism, Cambridge UP, Cambridge 2016. 
as $a$, if not the central principle of European integration. Vauchez shifts the attention from treaty-making to the more fundamental question of how European law established itself as a "field" in the Bourdieusian sense-a research approach that proves highly productive when studying judges from the European court, representatives of international law firms, academics, and others in their joint travails to establish a European legal field. European law, Vauchez goes on to argue, came to provide a unifying glue for a whole range of issues in a complex, disjointed multilevel polity, challenging political and economic logics of integration. With this claim, the book does not just help to fill a glaring empirical void; it also provides a rich conceptual framework to do so. ${ }^{20}$

Over the last few years, others have worked with similar approaches, deepening and further differentiating our knowledge on the issue. ${ }^{21}$ But law has risen to prominence in European integration research for other reasons too. After a long process of behind-the-scenes lobbying by the growing history of the EU law research community, the EU Court of Justice's recent decision to finally open its archives has facilitated robust empirical research on its role. This has led to several projects, often of an interdisciplinary nature. An edited volume by Fernanda Nicola and Bill Davies deserves particular mention. Bringing together lawyers, historians, and political scientists in an analysis of EU law cases, this book stands out due to the historical texture it adds to the Court's rulings. Like the work of Vauchez (who also contributes a chapter), the book underlines the wider societal context and the role that legal scholars and interested parties such as firms have played in the history of EU law. The authors of this collection confirm the standard story that, over time, EU law increasingly included broader powers and fundamental rights entailing a process of constitutionalization. However, they challenge the notion widely shared in the legal literature that this happened in a linear manner. Instead, they stress the bricolage character of this process. Many of these chapters manage to write about highly technical, legal details in an accessible way (though it is not a read that undergraduates will find easy), which further increases the book's relevance.

Like Vauchez' monograph, this volume is an excellent example of the innovative potential of European integration research and its relevance for other fields. ${ }^{22}$ Also beyond European integration, research in contemporary history has long ignored the role of law. Thanks to its conceptual sophistication and its important empirical findings, European integration history now has quite a bit to offer for scholars with other specializations. For this reason, experts of national politics, transnational movements, and other branches of international history might find this line of research inspiring.

\footnotetext{
${ }^{20}$ Vauchez, Antoine: Brokering Europe: Euro-Lawyers and the Making of a Transnational Polity, Cambridge UP, Cambridge 2015 (French original: Presses de Sciences Po, Paris 2013).

${ }^{21}$ See, for instance, Bailleux, Julie: Penser l'Europe par le droit. L'invention du droit communautaire en France, Dalloz, Paris 2014; Davies, Bill/Rasmussen, Morten (eds.): Towards a New History of European Law, in: Contemporary European History 21, 3 (2012) (special issue).

${ }^{22}$ Nicola, Fernanda/Davies, Bill (eds.): EU Law Stories: Contextual and Critical Histories of European Jurisprudence, Cambridge UP, Cambridge 2017, quote p. 3; on the legal field, also see the survey Schorkopf, Frank: Rechtsgeschichte der europäischen Integration. Ein Themengebiet für Grundlagenforschung in der Rechtswissenschaft, in: Juristenzeitung 69 (2014), pp. 421-472.
} 
To summarize: chronologically, research with a focus on institutional developments and the politics of creating a European polity has recently moved into the 1970s and 1980s, in line with the opening of state archives. With regard to their weight, diplomatic history no longer dominates the whole field, and especially the new interest in the role of law has led to a lot of innovation. Some studies, such as Grob-Fitzgibbon's, create links to other historical concerns, such as the history of empire and decolonization, adding urgency to the field. This point will be picked up again later; still, it should have become clear that the field is moving in very interesting new directions.

\section{The common market and beyond: policy fields and their relation to the economic and social history of Europe}

Beyond polity and politics, recent years have also seen important advances in analyzing key policies associated with European integration. A particularly important book in the field of European policies and their economic ramifications is Laurent Warlouzet's Governing Europe in a Globalizing World, an examination of how Western European governments coped with the challenges of globalization in the years from 1973 to 1986. Warlouzet argues that the reactions to the crises of the 1970s in the fields of economic policy were fraught with conflict, and that France, West Germany, and the United Kingdom (as the main foci of the book) did not see the EC as the obvious platform to regulate globalization. Nor was neoliberalism the obvious choice at the level of approach. Instead, Warlouzet underscores that the creation of the Single Market in the second half of the 1980s was the result of intense learning processes and an attrition of alternatives, ultimately leading to two choices. For one, it cleared the way for a more neoliberal course instead of its Keynesian and other alternatives at the level of economic policy. The other argument deals with the central forum to which these policy choices were directed. Accordingly, the three states ultimately opted for closer integration under the banner of the EC, but only after having tried out a more nation-centered approach as well as other forums such as GATT and the OECD. ${ }^{23}$

Warlouzet has written a fascinating and highly important book that stresses the openness of developments and that the EC's central position for Western Europe's international economic and social policies was by no means a given. This only becomes clear thanks to the book's methodological sophistication which combines a multi-perspective analysis of several states with an assessment of the EC and its contenders at the international level. The research is steeped in literature by political scientists and inspired by historical institutionalism which helps to keep the analysis compact and consistent despite the broad contextualization it offers. Of course, there is a price for this breadth: the book focuses on the tier of top political decisionmakers in the three wealthiest Western European states only. However, this price is very acceptable in light of what is gained, most importantly because the approach

\footnotetext{
23 Warlouzet, Laurent: Governing Europe in a Globalizing World: Neoliberalism and its Alternatives Following the 1973 Oil Crisis, Routledge, London/New York 2018.
} 
allows Warlouzet to avoid the teleological trap of seeing the EC as the obvious forum for economic governance. Beyond that, the book complicates the history of neoliberalism, thus contributing to another rising field of research in contemporary history. ${ }^{24}$ Warlouzet's Governing Europe in a Globalizing World therefore speaks to debates far beyond the confines of European integration history, and one can only wish it many readers.

Economic policies have formed a central part of the DNA of the integration process, and since the 1960s, debates about adding monetary policies to the existing institutions have slowly kicked in. They gained momentum with the demise of the Bretton Woods system which had provided a transatlantic scaffolding of Western Europe's monetary system until the early 1970s. While some studies have recently analyzed the early stages of the debates about a specifically Western European monetary order, ${ }^{25}$ others have already moved into the $1980 \mathrm{~s}$. A reference for future research in this field is Harold James's Making the European Monetary Union, a book that assesses the role of the Committee of Central Bank Governors in this process. Having benefited from privileged access to archival documents, most notably the Committee's files kept at the European Central Bank in Frankfurt as well material from the Bank for International Settlements, James goes back to the early 1960s when the Committee of Governors started its work. He ends in 1993 when the Committee was replaced by a new institution created under the auspices of the Maastricht Treaty. Convincingly, James argues that the quest for European monetary coordination was the result of a long learning process in reaction to a whole chain of monetary crises during the three decades under study; in that sense, it was more a response to problems of currency instability and misalignment than driven by overriding political considerations, such as the preservation of peace. James also shows how the set of actors pushing most for a European solution varied over time. While top-level politicians, including Helmut Schmidt and Valérie Giscard d'Estaing, played leading roles in the late 1970s, action during the crucial years roughly a decade later lay mostly in the hands of experts, chiefly the central bankers who tried to isolate themselves from political pressure. The book combines an immense depth of knowledge of economic and monetary processes with a thorough reconstruction of negotiations and deliberations, for which the Committee's detailed minutes are a real trove. James also dedicates quite some space to the international dimension of the European monetary project (with comparative references to US history, developments in the 19th century, and the role of other international forums in the field, such as the International Monetary Fund), all of which is very helpful. More work will certainly be needed to complement James's focus on the Committee of Governors with a deeper understanding of actors such as Kohl or Delors as state archives and those from the European Commission open their files for the late 1980s

\footnotetext{
24 Obviously, this goes beyond the scope of this review; recent key publications in this field include Ther, Philipp: Europe since 1989: A History, Princeton UP, Princeton, NJ/Oxford 2016; Slobodian, Quinn: Globalists: The End of Empire and the Birth of Neoliberalism, Harvard UP, Cambridge, MA/London 2018.

25 See most importantly Mourlon-Druol, Emmanuel: A Europe Made of Money: The Emergence of the European Monetary System, Cornell UP, Ithaca, NY 2012.
} 
and the 1990s. Still, this elegantly written book will be a reference for many years to come. ${ }^{26}$

James has co-authored another book, which moves the debate precisely to the role of the member states and the continuous differences between the monetary and economic concepts in Germany and France. This analysis, a collaboration with the economist Markus K. Brunnermeier and the former deputy governor of the Banque de France Jean-Pierre Landau, stands out as an interdisciplinary cooperation that intervenes more into a public debate than just a historiographical discussion. While going back to the pre-Maastricht period, it mainly seeks to explain the debates and developments over the past 25 years in order to elucidate the Euro's ongoing problems. To explain the various developments, it juxtaposes French and German economic traditions while also throwing in contextual factors. The result is an illuminating history of the most recent past. ${ }^{27}$

The Euro's problems and their historical roots are also the topics of a recent book by Dominik Geppert; similar to the volume by Brunnermeier, James, and Landau, it is an intervention into a current public debate, by means, however, of historical analysis. ${ }^{28}$ During earlier periods, publications of this kind often ended in a simple plea for "more Europe." These newer studies, in contrast, have become more cautious, particularly Geppert's book. In any case, they demonstrate that historical research on European integration is well able to comment on ongoing political developments.

Beyond these monographs, several edited volumes have recently contributed to this field of analyzing EC policies. One, edited by a team of French historians, highlights the economic dimension. The chapters deal with very different topics-from debates about social Europe in the interwar years, to a survey of military aviation during the Cold War, and on to a piece on how the Czech economy integrated into the EU. While some of the contributions contain fresh research, others summarize findings already published elsewhere; in all of them, the role of actors choosing economic integration is highlighted. Their contribution and impact cannot be generalized, as the editors readily admit. Beyond that, unfortunately, there is no strong analytical framework that holds the various pieces together. Still, readers might find individual chapters useful. ${ }^{29}$

Similarly, an edited volume by Jan-Otmar Hesse and others provides sweeping surveys on issues such as the history of social movements, banking, and finance,

\footnotetext{
26 James, Harold: Making the European Monetary Union, Harvard UP, Cambridge, MA/London 2012.

${ }_{27}$ Brunnermeier, Markus K./James, Harold/Landau, Jean-Pierre: The Euro and the Battle of Ideas, Princeton UP, Princeton, NJ/Oxford 2016.

${ }^{28}$ Geppert, Dominik: Ein Europa, das es nicht gibt. Die fatale Sprengkraft des Euro, Europaverlag, Munich 2013.

${ }^{29}$ Bussière, Éric/Dumoulin, Michel/Schirmann, Sylvain (eds.): Économies nationales et intégration européenne. Voies et Étappes, Steiner, Stuttgart 2014.
} 
or consumer societies for post-1945 European history. ${ }^{30}$ Many texts also provide an agenda for future research. As such, the book is a solid survey of the state of the art on the various issues at stake, while most of the articles stop short of breaking completely new ground. The disproportional attention paid to large Western European countries might also seem odd. And while the EC itself remains marginal in the majority of the texts, the various contributions can be helpful for researchers in integration history to orient themselves quickly on key contextual topics. Moreover, the book is a reminder of the continuous gap between integration research and social and economic history. Guido Thiemeyer is right, for instance, when he stresses that "vergleichende Studien zu europäischen Volkswirtschaften unter dem Einfluss der europäischen Integration" are missing. ${ }^{31}$ A lot of work remains to be done in this respect, and the same also holds true with regard to social history.

This is exactly where a volume edited by Arnd Bauerkämper and Hartmut Kaelble comes in. Over the past three decades, Kaelble has pushed for linking integration history to the history of European societies more than anybody, ${ }^{32}$ and this book is another plea to do so. Many of the chapters provide argument-driven surveys of their respective subjects, for instance Bo Stråth's text on social Europe or Georg Kreis' piece on development policy, but unfortunately, not all of them manage to establish a firm analytical and empirical link between wider societal processes and European integration (for example the chapter on migration). Even though the book's origins go back to a 2007 conference, it remains highly useful since it goes to the heart of conceptual and empirical problems in (re-)writing European integration history. ${ }^{33}$

Migration, as a particularly controversial issue in international debates today, is also the subject of Emmanuel Comte's succinct analysis of the "European migration regime," as he calls it, which for Comte was characterized by two factors: a de facto German hegemony and the regime's internal openness allowing for migratory flows. Comte thus contradicts most of the existing literature for which emigration countries played a major role in setting up this regime; for him, the Federal Republic with its economic and even more importantly its geopolitical interests led the way for the development of the European migration system. The book impresses with its intellectual rigidity, even if I do not find its argument entirely convincing, mostly because it overemphasizes the role of the Federal Republic and the national interests of one specific member state in EC policy-making. ${ }^{34}$ For the more recent period,

\footnotetext{
30 Hesse, Jan-Otmar e.a. (eds.): Perspectives on European Economic and Social History, Nomos, BadenBaden 2014, quote p. 7. This is the first book of a series on the economic and social history of modern Europe. In the meantime, several further volumes have been published. However, they are less relevant for this review than the first one; see https://www.nomos-shop.de/trefferListe.aspx?action=reihe \&reihe=481\& rtoc $=0$ (last accessed 20 March 2019).

31 Thiemeyer, Guido: Motive und Antriebskräfte wirtschaftlicher Integration, in: ibidem, quote p. 213.

32 See, most recently, Kaelble, Hartmut: Der verkannte Bürger. Eine andere Geschichte der europäischen Integration seit 1950, Campus, Frankfurt a. M./New York 2019.

33 Bauerkämper, Arnd/Kaelble, Hartmut (eds.): Gesellschaft in der europäischen Integration seit den 1950er Jahren. Migration-Konsum-Sozialpolitik—Repräsentationen, Steiner, Stuttgart 2012.

34 Comte, Emmanuel: The History of the European Migration Regime: Germany's Strategic Hegemony, Routledge, Abingdon 2018.
} 
it also tends to marginalize the external dimension of the migratory regime, the dimension that has lately led to the politically fiercest debates. ${ }^{35}$

Human rights is not just another hot topic in contemporary international history, it has also impacted this field. Victor Fernandez Soriano's Brussels PhD thesis deserves particular mention. He discusses how human rights issues were negotiated in Western Europe with regard to the Mediterranean dictatorships, most notably for the cases of Spain and Greece. ${ }^{36}$ The book sets itself a (possibly too) vast agenda by covering the long period from the late 1940s until the late 1970s. Importantly, it does not just deal with the EC, but also with the Council of Europe for which human rights played a much larger role than the EC. Fernandez Soriano is able to show that the EC's road to protecting human rights was long and difficult. During its early years, its powers and priorities lay in completely different fields. Others have written about various aspects of this topic before, but Fernandez Soriano's thesis helps to connect the dots and substantiate our knowledge through intense archival research - the list of archives expands over three pages. In a similar vein, Christian Salm has recently examined the role of transnational socialist networks in the EC's southern enlargement debates of the 1970s and also here, questions of human rights loom large. ${ }^{37}$

If Fernandez Soriano and Salm mainly focus on European human rights policies during the 1960s and 1970s, Marco Duranti's meticulous analysis of the Council of Europe's 1950 European Convention on Human Rights (ECHR) rethinks their very origins. He argues that British and French conservative top politicians (especially Winston Churchill) were central in shaping European human rights law; in fact, the ECHR's individualistic and conservative emphasis was chiefly meant to counter the rise of socialism and statism at the time. ${ }^{38}$ All these works thus contribute to historicizing human rights and to moving beyond triumphalist accounts. For the topic under study, they are particularly important because they draw the Council of Europe out from the EC's towering shadow among Western Europe's international organi-

\footnotetext{
35 See, with different arguments, for instance Calandri, Elena/Paoli, Simone/Varsori, Antonio (eds.): Peoples and Borders: Seventy Years of Migration in Europe, from Europe, to Europe, 1945-2015, in: Journal of European Integration History 23 (2017), (special issue); Romero, Federico: Emigrazone e integrazione europea, 1945-1973, Edizioni Lavoro, Rome 1991 and particularly the idea of a Europeanization of national migration regimes: Berlinghoff, Marcel: Das Ende der Gastarbeit. Europäische Anwerbestopps 1970-1974, Ferdinand Schöningh, Paderborn 2013.

36 Fernandez Soriano, Victor: Le fusil et l'olivier. Les droits de l'homme en Europe face aux dictatures méditerranéennes (1949-1977), Presses Universitaires de Bruxelles, Brussels 2015.

37 Salm, Christian: Transnational Socialist Networks in the 1970s: European Community Development Aid and Southern Enlargement, Palgrave Macmillan, Basingstoke/New York 2016.

38 Duranti, Marco: The Conservative Human Rights Revolution: European Identity, Transnational Politics and the Origins of the European Convention, Oxford UP, Oxford u. a. 2017.
} 
zations, while Fernandez Soriano also demonstrates how the Council of Europe's work came to inform the EC's early inroads in this field. ${ }^{39}$

Meanwhile, others have ventured into further fields of integration, such as Florian Seiller's research on the European Defense Community (EDC) discussions, which were ultimately aborted. ${ }^{40}$ Seiller focuses on Franco-German relations, particularly the hitherto neglected dimension of armaments cooperation, where French attempts to control Germany's military potential under the auspices of supranational planning loomed large. Arnd Herrmann examines a different organization and a later period in time by assessing the role of the Western European Union (WEU) in the course of the 1970s. The WEU's first predecessor as a security alliance was established in 1948. After the EDC's demise in 1954, the WEU was briefly assigned the task of helping Germany integrate into NATO. A few years later, when French President Charles de Gaulle vetoed the United Kingdom's accession to the EC, the WEU again acquired an important role. Others have already argued that during the years between the veto and the end of French blockage of British EC membership, the WEU helped to bridge the divide between the Community and the UK. Herrmann goes one step further and claims that beyond this specific assignment, it served as a crisis mechanism and a useful platform in three ways: firstly, between the EC member states; secondly, in their relationship to the UK and, thirdly, in attempts to forge closer foreign policy cooperation between the EC states. Herrmann's approach is interesting to the extent that it inserts the EC into a wider framework of international cooperation in Europe and hints at the interrelations between the various forums, even if such an analysis could have gone further. The other problem is that this book, as quite a few others in this field, concentrates on the three most powerful member states, thus sidelining the contributions from smaller member states. ${ }^{41}$

If the WEU was mainly concerned with military security, international terrorism led to an intensification of cooperation between the ministries of justice and the interior since the mid-1970s. Eva Oberloskamp's work on the "Trevi Group" breaks new ground, since she is able to base her findings on documents that have only become available recently. Convincingly, she demonstrates that during the 1970s, debates did not lead to much concrete joint action. More importantly, national governments learned from each other on questions of crisis management when facing terrorist attacks. The Trevi format had no legal basis in the Treaties of Rome (and was problematic from a democratic point of view) but still convened the respective ministers from the EC member states; it was only integrated into the formal structures of the

\footnotetext{
39 Particularly in Fernandez Soriano, Victor: Facing the Greek Junta: The European Community, the Council of Europe and the Rise of Human-Rights Politics in Europe, in: European Review of History 24 (2017), pp. 358-376. In general, the Council of Europe has recently started to receive more historiographical attention, see, e.g., Wassenberg, Birte: History of the Council of Europe, Council of Europe, Strasbourg 2013; as another example that inserts the Council of Europe into a broader international history and the history of European cultural diplomacy on a topic for which the EC/EU played no important role: Faure, Romain: Netzwerke der Kulturdiplomatie. Die internationale Schulbuchrevision in Europa, 1945-1989, Oldenbourg, Munich 2015.

40 Seiller, Florian: Rüstungsintegration. Frankreich, die Bundesrepublik Deutschland und die Europäische Verteidigungsgemeinschaft 1950 bis 1954, Oldenbourg, Munich 2015.

41 Herrmann, Arnd: Kriseninstrument WEU. Die Westeuropäische Union (WEU) in der EG-Erweiterungskrise 1963-1970, Steiner, Stuttgart 2015.
} 
EU with the Maastricht Treaty. From today's perspective, it might seem obvious that the EC was the forum to associate this new initiative with. Oberloskamp resists that temptation; she, too, places the EC in context by discussing why an association of this new initiative with other international organizations, such as the Council of Europe, was considered but ultimately dismissed at the time. ${ }^{42}$

Another recent book dealing with a policy field to be mentioned here is Isabel Tölle's comparison of the integration of Rhine navigation in the $1840 \mathrm{~s} / 1850 \mathrm{~s}$ and the 1950s/1960s, a topic in which the EC obviously only came to play a role in the later of the two periods without ever dominating the field. The book based on a PhD thesis at the University of Siegen's Institut für europäische Regionalforschungen, which in its book series has already published more than two dozen studies on the long-term perspective of European integration, often with a focus on infrastructure projects, a focus it shares with the Making Europe book series edited by Johan Schot and Phil Scranton. ${ }^{43}$ Given the strikingly different historical contexts, comparative work of the kind Tölle aims at is not easy; still, a clear scheme of criteria, taking its cue from political science, helps Tölle to navigate through the rich source material. In the analysis that results from this, the level of abstraction has to remain high; still, the book is a good example of the recent tendency to link post- 45 developments to longer trends and to assess them through the lens of comparisons and long-term continuities. ${ }^{44}$

A final development to be discussed in this section has to do with the role of borders in the context of integration history. Maybe the most obvious approach in this context is pursued by Angela Siebold in her analysis of the Schengen area, at least at first glance. ${ }^{45}$ Schengen, a 1985 agreement of five of the then ten EC member states, implied that internal border checks would be gradually abolished. While historical research on Schengen has only started recently, which is not surprising given the thirty-years' rule with regard to access to archival documents, ${ }^{46}$ Siebold does not analyze the negotiations resulting in the agreement, but rather the debates and perceptions of this process in Germany, France, and Poland. Including Poland gives this approach a particularly valuable twist, because it allows Siebold to ask how a Western European project was seen and debated before and after the caesura of 1989 in East-Central Europe. Schengen is a particularly interesting case in point, since it cannot simply be associated with an opening of borders, even if this view

\footnotetext{
42 Oberloskamp, Eva: Codename TREVI. Terrorismusbekämpfung und die Anfänge einer europäischen Innenpolitik in den 1970er Jahren, Oldenbourg, Munich 2017.

43 https://www.uni-siegen.de/phil/geschichte/lehrstuehle/wirtschaftsgeschichte/schriftenreihe/index.html (last accessed 20 March 2019); on Making Europe, see https://www.makingeurope.eu/www/en/home (last accessed 20 March 2019); the sixth (final) volume will be published in 2019.

44 On the latter, see, e.g., also Gross, Stephen G. (ed.): Visions of European Integration Across the Twentieth Century, in: Contemporary European History 26, 2 (2017), special forum; Kaiser, Wolfram/Patel, Kiran Klaus (eds.): Continuity and Change in European Cooperation during the Twentieth Century, in: Contemporary European History 27, 2 (2018), (special issue).

45 Siebold, Angela: ZwischenGrenzen. Die Geschichte des Schengen-Raums aus deutschen, französischen und polnischen Perspektiven, Schöningh, Paderborn 2013.

46 See especially Pudlat, Andreas: Schengen. Zur Manifestation von Grenze und Grenzschutz in Europa, Olms, Hildesheim 2013, also see the titles listed in note 62 on p. 27 in Siebold's book.
} 
dominates the EU's self-description. In 1995, for instance, when the Schengen states reduced internal border controls, they also hardened their external borders-with Poland sitting on the wrong side of the fence. Siebold's media analysis covers the years from the mid-1980s to 2007, and it is based on two quality newspapers from each of the three states. She shows that 1989 changed the parameters of the debate about a "borderless Europe" fundamentally, and added salience to the discussion (though the empirical analysis should have gone further in treating newspaper articles as sources in their own right not just as reflections of national debates). While this and some of the other findings of the book might not be so surprising, Siebold's work is very useful in transcending the Western European focus associated with the pre-1989/92 EC.

An even more interesting approach lies at the heart of Steffi Marung's Die wandernde Grenze, which grew out of her Leipzig PhD thesis. Like Siebold, Marung pays particular attention to Poland. Chronologically, she pushes the boundaries of research into the 1990s and the first decade of our century. Something else is more important: conceptually, she assesses the various layers of border-making, from the EU to the national and the local levels, while also including spaces in the vicinity of the EU. She summarizes these processes as the slow emergence of a new "Territorialisierungsregime," a term used to capture the production of political spaces beyond methodological nationalism. While the sub-national level and the voice of citizens experiencing this emerging Territorialisierungsregime would have deserved more attention, this book offers a conceptually productive way of reinserting EU history into European history and European Studies, even more so due to its interdisciplinary orientation with links to border studies, political geography, and further fields. ${ }^{47}$ While others have recently deepened our knowledge of how exactly people experience border regions as well as the administrative processes giving shape to them ${ }^{48}$, a recent book by Ulrike Jureit and Nikola Tietze offers a comprehensive summary of conceptualizing what they call "post-sovereign territoriality," along with the territorial notions that guided European integration. Like some of the edited volumes already cited, this publication results from multidisciplinary cooperation. It helps to inject integration history with new life by historicizing, contextualizing, and conceptualizing European territoriality as one of the hidden core categories of the integration process. ${ }^{49}$

All in all, research on European policies and their effects has become ever more diverse in recent years. This partly reflects the new possibilities for archive-based analyses on the 1970s and 1980s, when the EC increasingly ventured into new policy domains. More fundamentally, it demonstrates that the limits of the field have become fuzzier, mainly for good reasons. The EC/EU is no longer seen as "the only game in town" at the level of European transnational governance, as particularly

\footnotetext{
47 Marung, Steffi: Die wandernde Grenze. Die EU, Polen und der Wandel politischer Räume, 1990-2010, Vandenhoeck \& Ruprecht, Göttingen 2013.

48 Prettenthaler-Ziegerhofer, Anita/Kißener, Michael/Kusber, Jan (eds.): Zwischenräume. Grenznahe Beziehungen in Europa seit den 1970er Jahren, Studienverlag, Innsbruck 2011.

49 Jureit, Ulrike/Tietze, Nikola (eds.): Postsouveräne Territorialität. Die Europäische Union und ihr Raum, Hamburger Edition, Hamburg 2015.
} 
the research on human rights demonstrates. Beyond state actors, transnational actors have gained more attention, though the last five years have seen slightly less research highlighting this dimension than the decade before. ${ }^{50}$ Instead, their role is taken for granted. A hotter topic are the links between various forums, such as the WEU and the EC, complicating the story of the EC as the only or even the main alternative to a state-centered approach of policy-making in Western Europe. And beyond policy-making, integration's actual effects along with the links to the wider social, economic, and political history of Europe now receive more attention, even if a lot remains to be done. And, as a final move in this field, some studies have even crossed the line into the post-Cold War era, which further helps to complicate the story and forge connections to our present age.

\section{Making sense of Europe: popular perceptions, support, and notions of Europe}

Over the past two decades, research on the public perception of European integration and the role of the media has become ever more prominent. Some studies have examined the question in its own right, while others are more interested in the extent to which integration has impacted self-images. The link to questions of identity is still present, even if, in comparison to earlier years, recent research has become more hesitant to talk about a straightforward European identity. Having said this, scholars are highly interested in how citizens have related to European integration. Marginal in the early stages of European integration research, publications that address these kinds of questions and that in one way or another build on the cultural turn have risen to prominence in recent years, and at least some of these recent advances shall be briefly discussed here.

To start with the latter point, there is now doubt that European integration mainly unfolded through top-level negotiations between politicians, civil servants, and representatives of transnational interest groups. But at crucial junctures European citizens spoke up to express support or dissatisfaction with the EC or addressed European affairs in other forums. Frederike Neißkenwirth's analysis of the cooperation between Dutch and German federalist factions of the European movement in the first dozen years after World War II is only one of several studies that have deepened our knowledge on this issue lately. Neißkenwirth's focus on the Netherlands is particularly welcome, since federalist activism was strong there during the early postwar years and since her work counterbalances the usual bias toward large member states. In line with earlier research, her work demonstrates that the high tide of civil engagement was already long over by the time the European Economic Community was established. Having said that, the book comes up with interesting insights at the comparative and the transnational level. Moreover, it pushes the boundaries of research on these groups in the two countries further into the 1950s in comparison to

\footnotetext{
50 See, e.g., Kaiser, Wolfram/Meyer, Jan-Henrik (eds.): Societal Actors in European Integration: PolityBuilding and Policy-Making, 1958-1992, Palgrave Macmillan, Basingstoke/New York 2013.
} 
earlier studies. We thus learn how they adjusted their self-understanding to changing political and cultural environments. ${ }^{51}$

The latter also holds true for Christine Norwig's research on the European Youth Campaign from 1951 to 1958 , another forum of civil society engagement at the time. Norwig discusses the various activities of the Campaign. The book makes interesting inroads into the cultural dimension of European integration, analyzing the activists" ideas about "youth" and notions of a new generation. Still, its overall findings are not totally convincing: while it is true that symbolically, young activists played a central role, their work logistically and financially depended much on an older generation and particularly on transatlantic support, for instance from highranking US business leaders, diplomats, and intelligence officers. When American financial help petered out, the Campaign quickly folded-a finding that qualifies some of the idealistic self-descriptions of the Campaign's protagonists that Norwig tends to import into her analytical framework. A clearer distinction between images and practices would have been useful. ${ }^{52}$

Others go further back in time than Neißkenwirth and Norwig. Willy Buschak's book examines the views of the labor movement on European integration during the interwar period. He mainly focuses on debates in Germany but also throws in information on other countries. ${ }^{53}$ While helping to fill a lacuna and accumulating a lot of interesting sources, the book is ultimately a reminder of how little we still know about such pro-European movements and activities before 1945. Patrick Bredebach picks up Buschak's thread in his analysis of German and Italian Christian and Social democrats and their notions of Europe during the first two postwar decades. As in Buschak's work, the rank and file delegates, let alone normal party members and followers, remain largely below the radar. ${ }^{54}$ Not only for the interwar years, but also for the postwar period, a lot of work remains to be done, especially on how citizens in and beyond the member states related to pro-European ideas and the EC more specifically. This holds particularly true for the time since the 1960s and again especially if one leaves the realm of ideas and focuses more on practices and concrete forms of civic engagement.

Antonin Cohen opts for a very different direction and looks at a small group of intellectuals and their impact on the 1950 Schuman plan. He argues that particularly the idea of a supranational authority had roots in the 1930s' and 1940s' thirdway corporatism and personalism with its proclivity to the far right. Hence the book's polemic title De Vichy à la Communauté européenne. The analysis singles out a specifically French line of tradition, the long-term influence of which should not be overestimated. Still, the book is a useful reminder that postwar integration

\footnotetext{
${ }^{51}$ Neißkenwirth, Frederike: "Die Europa-Union wird Avantgarde bleiben". Transnationale Zusammenarbeit in der niederländischen und deutschen Europabewegung (1945-1958), Waxmann, Münster 2016.

52 Norwig, Christina: Die erste europäische Generation. Europakonstruktionen in der Europäischen Jugendkampagne 1951-1958, Wallstein, Göttingen 2016.

${ }^{53}$ Buschak, Willy: Die Vereinigten Staaten von Europa sind unser Ziel. Arbeiterbewegung und Europa im frühen 20. Jahrhundert, Klartext, Essen 2014.

${ }^{54}$ Bredebach, Patrick: Das richtige Europa schaffen. Europa als Konkurrenzthema zwischen Sozial- und Christdemokraten. Deutschland und Italien von 1945 bis 1963 im Vergleich, Vandenhoeck \& Ruprecht, Göttingen 2013.
} 
had far more diverse roots (including some tainted ones) than the protagonists of the process claimed later on. ${ }^{55}$ This point has recently also been underscored by others, for instance by Robert Salais. ${ }^{56}$

The relationship between mobilization and European integration is further complicated by a recent collection that examines abstention, Euroscepticism, and "antieuropéisme" in European elections since 1979, when the European Parliament (EP) was elected directly for the first time. According to its introduction, this edited volume is interested in the paradoxical nexus between elections and resistance against European integration, that is whether elections might further forms of EU criticism. The empirical chapters bring together an interdisciplinary and highly international mix of authors; formally, the trilingual book would have needed a serious round of editing. Content-wise, it nuances our understanding of the issue at stake. Still, it is hard to discern a single answer to the question raised in the book's introduction. ${ }^{57}$ This as well as two further volumes on the topic came to us from the University of Strasbourg, which, in general, is one of Europe's centers of interdisciplinary research on European integration, particularly with a focus on elections. The other two, coedited by political scientist Patrick Moreau and historian Birte Wassenberg, deal with the 2014 EP elections and what the editors call "new Anti-Europeanism". ${ }^{58}$ Many contributions are useful, even if there is no clear-cut set of categories that holds the chapters together, for instance an agreement on what counts as "old" and "new" forms of anti-Europeanism. In general, the reminder of Wilfried Loth's conclusion in the 1979 book also applies here: we still need further work on terminology and clearer distinctions between normative and analytical terms, since some forms of anti-Europeanism might simply call for a different vision of Europe than the one associated with the EC/EU. ${ }^{59}$

This is also where a final book of this genre fits in. Dieter Gosewinkel has edited a volume on "anti-liberal Europe" which he sees as a form of Europeanization. Its various chapters, many of which result from $\mathrm{PhD}$ theses and other qualification work from Germany over the past decade or so, delve into the various anti-liberal discourses about Europe, from colonialism and Nazism to conservative and socialist visions (which, obviously, did not just imply various definitions of Europe, but also of (anti-)liberalism, with the latter term becoming vaguer as the book continues). The recent rise of anti-liberal notions of Europe makes this book highly topical, while in historiographical terms, it is a useful reminder that not all ideas of Europe

55 Cohen, Antonin: De Vichy à la Communauté européenne, Presses universitaires de France, Paris 2012.

56 Salais, Robert: Le viol d'Europe. Enquête sur la disparition d'une idée, Presses Universitaires de France, Paris 2013, especially pp. 127-150.

57 Libera, Martial/Schirmann, Sylvain/Wassenberg, Birte (eds.): Abstentionnisme, euroscepticisme et antieuropéisme dans les élections européennes de 1979 à nos jours, Steiner, Stuttgart 2016.

58 Moreau, Patrick/Wassenberg, Birte (eds.): European Integration and New Anti-Europeanism. vol. 1: The 2014 European Election and the Rise of Euroscepticism in Western Europe. vol. 2: The 2014 European Election and New Anti-European Forces in Southern, Northern and Eastern Europe, Steiner, Stuttgart 2016. A third volume, which does not deal with the 2014 EP election but with perceptions of external states on European integration, came out in 2017.

59 Loth, Wilfried: Conclusion/Conclusion/Schlußfolgerung, in: Libera/Schirmann/Wassenberg: Abstentionnisme, euroscepticisme et anti-européisme, pp. 231-239. 
are associated with liberal democracy. Put differently, anti-liberal ideas of Europe were not necessarily anti-European. ${ }^{60}$

Closely related to such studies with their interest in citizens' reactions to and involvement in European integration (as well as its contenders) is the research that assesses public perceptions of European integration and sometimes links it to identity-related issues. Almost all studies of this kind base their research on social constructivist premises. They often refer to Benedict Anderson and his concept of imagined communities, with the idea of transposing such work on nationalism to the European tier. Hence, they see the term "Europe" as polysemic, as for instance in a co-authored book by Chiara Bottici and Benoît Challand with the programmatic title Imaging Europe. Their analysis opens with the sentence: "Europe has not always been there." Bottici and Challand underline that Europe's existence as a political object is comparably recent, and the various chapters of their book (most of which build on their earlier articles published elsewhere) offer stimulating ideas about key concepts at stake, particularly on narratives, memory, myths, and identity. They also provide empirical evidence, but at that level, others have in the meantime gone further in this quickly expanding field. Hence, the book is particularly relevant thanks to its theoretical and conceptual deliberations. ${ }^{61}$

A lot of the empirical research on images of Europe focuses on analyzing the media. One study of this kind is Sven Leif Ragnar de Roode's examination of the British, West German, and Dutch press. ${ }^{62}$ De Roode asks how national selfimages have impacted on the perception of European integration and vice versa. He proceeds with an examination of editorials on several moments during the 1950s as well as the Maastricht Treaty for the 1990s; unfortunately, the thirty years in between remain a black hole. In line with some of the earlier research, de Roode stresses the national specificities of the perceptions of European integration, for instance the high moral grounds of the Dutch debate during the 1950s. Still, he-like many others-does not just distinguish national differences, but also between media outlets within a country, reflecting their respective readerships. For all this, he provides a lot of evidence. Unfortunately, we learn much less on his second research question, in other words on how "the process of European integration impacted on national selfimages" (p. 43), and given his source base, he can hardly provide satisfying answers to questions of causality.

De Roode's strong emphasis on the prevalence of national self-images, best summarized in the book's title Seeing Europe through the Nation is qualified in light of other recent studies on the role of the national in framing Europe. One example is

\footnotetext{
60 Gosewinkel, Dieter (ed.): Anti-liberal Europe: A Neglected Story of Europeanization, Berghahn Books, New York 2015. While the book thus has its clear merits, it should not be forgotten that Walter Lipgens (1925-1984), one of the pioneers of European integration history, already included anti-liberal ideas and concepts into his multi-volume collection: Walter Lipgens (ed.): Documents on the History of European Integration, 4 vols., De Gruyter, Berlin 1985-1991.

61 Bottici, Chiara/Challand, Benoît: Imagining Europe: Myth, Memory, and Identity, Cambridge UP, Cambridge 2013.

62 Roode, Sven Leif Ragnar de: Seeing Europe through the Nation: The Role of National Self-Images in the Perception of European Integration in the English, German, and Dutch Press in the 1950s and 1990s, Steiner, Stuttgart 2012.
} 
Ariane Brill's analysis of the West German, British, and US-American press from 1945 to 1980 . In contrast to de Roode, she does not just examine editorials, but all kinds of articles, partly building her argument on digital repositories of the various newspapers under study. ${ }^{63}$ She also transcends de Roode's focus on political and economic integration and includes other notions of Europe, for instance in articles about culture or sport. On this basis, she demonstrates that "Europe" was mostly associated with Western Europe, but not necessarily with the EC/EU. Moreover, she sees a tendency of Europeanization in press reporting, meaning an increasing synchronicity of the European issues on which journalists reported. Her findings are in line with slightly older research, such as Jan-Henrik Meyer's analysis of the media and transnational communication in European integration, who also pointed at such media cross-references and other traits of a European public sphere. ${ }^{64}$ Brill also underlines the continuous importance of delimiting Europe from other parts of the world-which did not just include other continents, but also Eastern Europe or regions perceived as peripheral, such as Greece. Brill's non-essentialist and nonEU-centered approach is very useful, even if it would have been good to broaden the scope of newspapers beyond one case per country.

Brill's book is based on a $\mathrm{PhD}$ thesis prepared as part of a wider research project, and for our context, the most relevant other book is Florian Greiner's, in which he assesses the same three countries for the years preceding Brill's study, from 1914 to 1945 . He, too, underlines the continuous relevance of references to Europe in media debates. Moreover, Greiner stresses that "Europe" was not just associated with crisis, but also with projections and visions for the future-and this did not just hold true for liberal democrats, but for instance also for representatives of the far right. ${ }^{65}$ Like Brill's book, and a volume they both co-edited with project director Frank Bösch, this research expands our knowledge about discourses on Europe, both within and beyond a focus on European integration research. The latter is truer still for their edited volume, in which some (though not all, despite the book's title) contributions highlight perspectives and voices beyond the large states of Western Europe. Building on earlier research, they also pay particular attention to how discussions were shaped by delimitating oneself from a non-European other. ${ }^{66}$

The key role of delimitation in ideas about Europe is also highlighted in a monograph by Patrick Pasture. In just 200 text pages, he covers no less than 1000 years of debate about creating peace in Europe. Pasture's work challenges the old, federalist narrative according to which ideas slowly gained momentum until they impacted upon politics after 1945. Inspired by postcolonial studies and global history, he highlights the impact of colonial heritage. He also pays greater attention to religion

\footnotetext{
${ }^{63}$ Brill, Ariane: Abgrenzung und Hoffnung. "Europa" in der deutschen, britischen und amerikanischen Presse, 1945-1980, Wallstein, Göttingen 2014.

${ }^{64}$ Meyer, Jan-Henrik: The European Public Sphere: Media and Transnational Communication in European Integration, 1969-1991, Steiner, Stuttgart 2010.

${ }^{65}$ Greiner, Florian: Wege nach Europa. Deutungen eines imaginierten Kontinents in deutschen, britischen und amerikanischen Printmedien 1914-1945, Wallstein, Göttingen 2014.

${ }^{66}$ Bösch, Frank/Brill, Ariane/Greiner, Florian (eds.): Europabilder im 20. Jahrhundert. Entstehung an der Peripherie, Wallstein, Göttingen 2012; as an earlier piece of research with a somewhat similar approach, see Stråth, Bo (ed.): Europe and the Other and Europe as the Other, Lang, Brussels 2000.
} 
than most other authors. While being surprisingly brief on the postwar decades, this short book opens up many new perspectives; it is essential to bring the old debate about "European peace," especially for the period before 1945, up to the state of the art. ${ }^{67}$

Europe's Utopias of Peace by Bo Stråth raises a similar question. This publication by the highly productive Swedish historian charts three major attempts to create lasting peace in Europe's modern history. Stråth's choice to pair 1951 with 1815 and 1919 might come as a surprise, since most historians would not attribute the same significance to the creation of the European Coal and Steel Community (the EU's oldest predecessor) as they would to Vienna and Versailles. Stråth's approach does make sense to the extent that he focuses on plans and ideas, or what he calls "utopian formulations" and since he concedes that this third Utopia was no longer about world peace, but only about Western Europe. That he adds long deliberations on negotiations and politics reduces the book's consistency, however. In the framework of the overall claim, Stråth tends to imbue the 1951 Paris Treaty with a significance it hardly deserves, also since many recent studies deemphasize its role and instead stress the EC's slow and incremental gain in relevance since the 1950s. Equally, his description of the EC's demise is rather sweeping. Still, this unconventional and thought-provoking book deserves applause for its long-term perspective. ${ }^{68}$

This brings us back to other publications on how people made sense of Europe, particularly during the 20th century. Not all of this research focuses on media analysis and ideas. Other forums and ways in which these questions have been negotiated have gained attention too, such as the symbols and symbolic forms of representation of the EU and their history. A book co-edited by Guillaume Bourgeois and Hélène Yèche is not the first to address the topic (though the short introduction and some of the chapters do not seem to be aware of the non-French literature) but includes some recent developments in this context. ${ }^{69}$ There is also new research on how pro-European journals viewed European integration-such as an edited volume by a group of Italian scholars that contains some useful chapters, but offers no conceptual framework in which these are imbedded. ${ }^{70}$

Much more sophisticated is Eugen Pfister's analysis of how newsreels imagined Europe during the first decade of the Cold War. The book based on his $\mathrm{PhD}$ is impressive due to its methodological sophistication. Readers might find the book heavy on theory, but that is also one of its assets, in that it draws on several disciplines and for instance considers the iconographic traditions in which these postwar images have to be placed. Empirically, it argues that images of Europe in Austria, France, the United Kingdom, and Germany converged transnationally on several messages,

\footnotetext{
67 Pasture, Patrick: Imagining European Unity since 1000 AD, Palgrave Macmillan, Houndmills 2015.

68 Stråth, Bo, Europe's Utopias of Peace: 1815, 1919, 1951, Bloomsbury, London/New York 2016. Some of his arguments have striking similarities to Salais's Le viol d'Europe.

69 Bourgeois, Guillaume/Yèche, Hélène (eds.): Signes, couleurs et images de l'Europe, Presses Universitaires de Rennes, Rennes 2011.

70 Pasquinucci, Daniele/Preda, Daniela/Tosi, Luciano (eds.): Communicating Europe: Journals and European Integration, 1939-1979, Lang, Brussels 2013. The book suffers from a lack of proper languageediting.
} 
although in various shades and combinations. Despite these differences, they all aimed at giving legitimacy to the political efforts of European integration. This finding is interesting, but it narrows down "Imaginationen Europas" to images of European integration, whereas others, such as Brill, do its polysemic character more

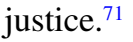

Gabriele Clemens' volume on the construction of European identity through audio-visual media, notably documentaries and other short films, widens this canvas even further by going beyond newsreels. The various chapters deal with films produced by the EC institutions themselves, but also by other international organizations as well as national agencies between the late 1940s and the late 1960s, asking how they sought to foster a European identity. This well-composed book is much more than the usual edited volume, and it deals with an impressive range of sources. ${ }^{72}$ Maria Fritsche starts even a little bit earlier and explores the use of Marshall Plan films including their reception among Europeans. ${ }^{73}$ A related topic is dealt with in Alexander Reinfeldt's analysis of the information policy of EC institutions until the early 1970s, resulting from a PhD thesis supervised by Clemens. Reinfeldt shows convincingly that such campaigns and policies mainly targeted the elites, especially opinion leaders, opinion formers, and specialist audiences. ${ }^{74}$ The book does not just discuss contents, but also their institutional background and highlights the infighting between several EC bodies in charge of this field. ${ }^{75}$ Information, as he convincingly argues, was seen as a means of integration, and this succinct formula also summarizes some of the main findings of Clemens', Fritsche's, and Pfister's books.

All in all, research in this broad field of public support, perceptions, and images of Europe has led to many new insights. In contrast to some ten years ago, the focus on European identity has moved a bit into the background, not least due to the methodological challenges such research has to face. Moreover, it mirrors the more nuanced picture we have today, with a polysemic image of Europe that was never monopolized by the EC/EU, and a stronger interest in forms of resistance now counterweighing studies on support of any concept or notion of Europe(an integration). Finally, there is an increasing interest in how the process of European integration has been and is being commemorated and presented in public speeches, news reports, and museums, and how this has changed over time. This also reflects the new attention to narratives of integration and their role within the process, as well as its ideational and symbolic dimensions, which at the same time strengthen

\footnotetext{
${ }^{71}$ Pfister, Eugen: Europa im Bild. Imaginationen Europas in Wochenschauen in Deutschland, Frankreich, Großbritannien und Österreich, 1948-1959, Vandenhoeck \& Ruprecht, Göttingen 2014.

${ }^{72}$ Clemens, Gabriele (ed.): Werben für Europa. Die mediale Konstruktion europäischer Identität durch Europafilme, Schöningh, Paderborn 2016.

${ }^{73}$ Fritsche, Maria: The Marshall Plan Film Campaign and the Europeans, Bloomsbury, London/New York 2018

${ }^{74}$ Reinfeldt, Alexander: Unter Ausschluss der Öffentlichkeit? Akteure und Strategien supranationaler Informationspolitik in der Gründungsphase der europäischen Integration, 1952-1972, Steiner, Stuttgart 2013.

75 A dimension that is missing in one of the other recent studies assessing the role of EU institutions and the images they project: Schrag Sternberg, Claudia: The Struggle for EU Legitimacy: Public Contestation, 1950-2005, Palgrave Macmillan, Basingstoke/New York 2013; a book that is interesting because it zooms in on the debate about EU legitimacy as a more specific topic.
} 
the links to memory, media, and museum studies along with cultural studies more broadly. ${ }^{76}$

Having said this, many questions remain open. To mention just three: firstly, in the field of media analysis, most studies still resort to examining outlets in one medium, mostly quality newspapers. While other parts of the press deserve more attention, we also lack analyses that cover the overall mass-media ensemble. Besides, the new digital opportunities have not yet been explored to their fullest extent. Also, the producers of the media contents deserve more attention, as well as their infrastructure, motives, and the intrinsic logic of the media, beyond the contentanalysis that continues to dominate many studies. Secondly, and this holds true for the field more generally, there are clear chronological imbalances. A particular lacuna exists for civic engagement and public perceptions during the 1970s and 1980s, that is beyond the first postwar decades and before the 1990s and more recent periods, for which we have a lot of studies by social scientists. Thirdly, many of the cited studies claim to bring in bottom-up perspectives. And while many go beyond the official declarations by national politicians and EU representatives, almost all focus on elite groups-be it student activists at a time when some five percent of the population attended universities or journalists and filmmakers. Research on how average citizens have experienced, negotiated, and performed "Europe" remains immensely difficult. Pfister is one of the few who at least dare to speculate about this issue, and Fritsche has a strong chapter on how Europeans reacted to the Marshall Plan films. Future research has to go further in trying to provide answers to such probing questions.

\section{The Cold War and beyond: integration in a global world}

Recent years have seen renewed efforts to insert integration history into a broader analysis of international politics. Some of the work deals with the new institutions and governance mechanisms set up to that end; many others examine the relationship of Europe's international institutions with other parts of the world. Here too, research has mushroomed and topics have become more diverse. More importantly, there are new connections to other debates in European, international, and global history that make recent advances relevant also for readers beyond this field.

Transatlantic relations and the role of the United States have been an important topic of this kind of research since the 1980s; in fact, the analysis of the Marshall Plan as one of the first attempts to foster transatlantic and European cooperation

\footnotetext{
76 See, e.g., Krumrey, Jacob: The Symbolic Politics of European Integration: Staging Europe, Palgrave Macmillan, Basingstoke/New York 2018; several of the contributions in Sierp, Aline/Wüstenberg, Jenny (eds.): Transnational Memory Politics in Europe: Interdisciplinary Approaches, in: Journal of Contemporary European Studies 23, 3 (2015), (special issue); Kaiser, Wolfram/Krankenhagen, Stefan/Poehls, Kerstin (eds.): Exhibiting Europe in Museums: Transnational Networks, Collections, Narratives and Representations, Berghahn Books, New York 2014; Calligaro, Oriane: Negotiating Europe: The EU Promotion of Europeanness since the 1950s, Palgrave Macmillan, Basingstoke/New York 2013.
} 
was an important springboard for studying European integration. ${ }^{77}$ If research during the 1980s concentrated on the 1940s, recent work has pushed the chronological boundary closer to the present, with an empirical focus today mainly on the 1970s and the 1980s. This has led to new studies, for instance on the Nixon administration's interaction with Western Europe. Luke A. Nichter's Richard Nixon and Europe does not just examine transatlantic relations with regard to the EC, but also NATO, monetary policies, and the Anglo-American relationship. In doing so, he follows the trail of established diplomatic history. The book is a well-researched contribution to the issue, and it is striking how the debates of the early 1970s resonate with the difficult US-European relations of today. ${ }^{78}$ Kissinger's infamous Year of Europe initiative, which Nichter covers mainly from the American side, is also the subject of a chapter in Maria Găinar's analysis of the European Political Cooperation's (EPC) history, forerunner of the EU's foreign policy coordination. Her work, however, is much broader and deals with the EPC's development in the second half of the 1970 s, combining a history of this policy tool with several case studies on how it was deployed in relation to various world regions. As such, Găinar builds on Daniel Möckli's pioneering monograph of the EPC's very first years. ${ }^{79}$ While rendering important insights, Găinar's monograph suffers from relying almost exclusively on French official sources along with papers from actors within the European institutions, while omitting other national perspectives - an approach that is even more problematic for the European side than in Nichter's case for the American. ${ }^{80}$ In contrast, the Quest for Europeanization, edited by Gabriele Clemens, builds on a more sophisticated approach. Most of the contributions use the EC/EU's external and foreign policies as test cases to assess whether European integration has led to a Europeanization of political practices in member states and European institutions. The book, which brings together contributions from several disciplines, thus follows some of the conceptual debates in political science and highlights the limits of such Europeanization, but also how particularly smaller member states used the EPC to carve out new political options. ${ }^{81}$

Others have recently deepened our knowledge on the interaction with neighboring countries, for instance Simon Marti with his analysis of Switzerland's European politics during the European Economic Area-negotiations from 1988 to 1992. Marti's book pushes the chronological boundaries of archive-based research like hardly any other in this field and carefully weighs political and economic aspects. However, it

\footnotetext{
77 Patel, Kiran Klaus: Europäische Integrationsgeschichte auf dem Weg zur doppelte Neuorientierung, in: Archiv für Sozialgeschichte 50 (2010), pp. 598-599.

78 Nichter, Luke A.: Richard Nixon and Europe: The Reshaping of the Postwar Atlantic World, Cambridge UP, Cambridge 2015.

79 Möckli, Daniel: European Foreign Policy during the Cold War: Heath, Brandt, Pompidou and the Dream of Political Unity, I.B. Tauris, London 2008.

80 Găinar, Maria: Aux origines de la diplomatie européenne. Les Neuf et la Coopération politique européenne de 1973 à 1980, Lang, Brussels 2012.

81 Clemens, Gabriele (ed.): The Quest for Europeanization: Interdisciplinary Perspectives on a Multiple Process, Steiner, Stuttgart 2017.
} 
also almost exclusively focuses on one side of the actors (in his case the Swiss), and unfortunately stops before the decisive referendum in December $1992 .{ }^{82}$

Another volume in this field, covering a much longer period of time and a bilateral relationship, is Günal Incesu's examination of German-Turkish relations in the context of Turkey's attempt to access the EC from 1959 to $1987 . .^{83}$ The book is less concerned with diplomatic interactions; instead, it zooms in on the two countries' respective public spheres and mutual perceptions. Ultimately, Incesu stresses that at the level of public debates and discourse, the Federal Republic played a key role for the relations between the EC and Turkey.

Perceptions are also at the center of Martin Weber's book on Soviet and later Russian historiography and its views of European integration since 1985. The book offers some interesting insights, even if its analytical focus could have been stronger. Additionally, the text organization is not fully convincing. ${ }^{84}$ Conceptually more interesting is Christian Domnitz' book on the "Öffentlichkeitswandel im Staatssozialismus" from 1975 to 1989 which he summarizes as a "Hinwendung nach Europa." Domnitz assesses the various narratives of Europe as they unfolded in Poland, Czechoslovakia, and the GDR in the last fifteen years before the end of the Cold War. The comparative perspective is particularly useful. Moreover, Domnitz shows how informal contacts with the West helped to transform narratives, and how Europe increasingly turned into a meaningful category with positive connotations. Even less than in Western Europe, however, "Europe" was reduced to the European Community; instead, the book reveals that visions of Europe remained rich and decisively diverse. If an international organization figured in such debates, it was the Conference for Security and Co-operation in Europe, not the EC. ${ }^{85}$ The book is therefore a stark reminder that not all roads led to today's EU.

Beyond perceptions, several new publications have recently challenged the pervasiveness of the East-West divide during the Cold War in Europe and assessed loopholes and other transnational connections across the Iron Curtain. One recent book of this kind was edited by Simo Mikkonen and Pia Koivunen. To avoid a misunderstanding: the predecessors of today's EU play no big role in this collection, but several of its chapters demonstrate that other international organizations helped to link East and West. One example is Lars Lundgren's chapter on the European Broadcasting Union (EBU), which established a common framework for the produc-

\footnotetext{
82 Marti, Simon: Schweizer Europapolitik am Wendepunkt. Interessen, Konzepte und Entscheidungsprozesse in den Verhandlungen über den Europäischen Wirtschaftsraum, Nomos, Baden-Baden 2013.

83 Incesu, Günal: Ankara-Bonn-Brüssel. Die deutsch-türkischen Beziehungen und die Beitrittsbemühungen der Türkei in die Europäische Gemeinschaft, 1959-1987, transcript, Bielefeld 2014; on Franco-German relations, as the most classical topic in this context, see, e.g., Koopmann, Martin/Schild, Joachim/Stark, Hans (eds.): Neue Wege in ein neues Europa. Die deutsch-französischen Beziehungen nach dem Ende des Kalten Krieges, Nomos, Baden-Baden 2013.

84 Weber, Martin: Ein Europa? Die europäische Integration in der russischen Historiographie nach 1985, Böhlau, Cologne 2013.

85 Domnitz, Christian $(\dagger)$ : Hinwendung nach Europa. Neuorientierung und Öffentlichkeitswandel im Staatssozialismus, 1975-1989, Artemis \& Winkler, Munich 2015; see also the collection Faraldo, José M./Gulińska-Jurgiel, Paulina/Domnitz, Christian (eds.): Europa im Ostblock. Vorstellungen und Diskurse (1945-1991), Böhlau, Vienna 2008.
} 
tion and transmission of live transnational television despite the Cold War divide. Simultaneously, EBU was competing fiercely with its Eastern contender, the International Organization of Radio and Television, in its relations with non-European countries. Many of the other chapters deal with popular culture, grassroots action, and other issues in which the EC/EU did not play a role. ${ }^{86}$ This is different in Suvi Kansikas' and Angela Romano's analyses of the East-West trade from the perspective of the Council for Mutual Economic Assistance (CMEA). Kansikas shows how its Eastern allies increasingly induced the Soviet leadership to accept the CMEA's opening towards the EC; conversely, Romano stresses that during the Helsinki process, the EC often managed to speak with one voice-thus emerging as an actor in international politics as a stature that it did not acquire in many other global contexts. ${ }^{87}$ Its new role became particularly significant during the first half of the 1980s, when superpower tensions spiked again. Europeans on both sides of the Iron Curtain drifted further than ever before from the lines dictated by Washington and Moscow. The EC played a significant part in this, with trade cooperation in particular keeping lines of communication open. ${ }^{88} \mathrm{~A}$ final recent book in this context is Benedetto Zaccaria's publication of the EEC's attitude towards Yugoslavia during the 1970s, which deserves particular attention given Yugoslavia's special position in Cold War Europe. This position, as well as the perceived need to counter Soviet expansion in the Balkans, were reasons why the EEC was able to establish itself as a significant actor in the region. ${ }^{89}$

All these findings are not just interesting in their own right. They also speak to much larger historiographical concerns. Most importantly, they help to nuance and qualify the Cold War narrative. In recent years, the Cold War has been challenged in its status as the once defining analytical framework to assess post-1945 history. Some have argued for the need to take off the Cold War lens to understand global North-South relations during that period; others have gone even further in chal-

\footnotetext{
${ }^{86}$ Mikkonen, Simo/Koivunen, Pia (eds.): Beyond the Divide: Entangled Histories of Cold War Europe, Berghahn, Oxford/New York 2015; as recent studies with a similar thrust see, e.g., Reichherzer, Frank/ Droit, Emmanuel/Hansen, Jan (eds.): Den Kalten Krieg vermessen. Über Reichweite und Alternativen einer binären Ordnungsvorstellung, De Gruyter, Berlin 2018; Bange, Oliver/Villaume, Poul (eds.): The Long Détente: Changing Concepts of Security and Cooperation in Europe, 1950s-1980s, CEU Press, Budapest 2017; Autio-Sarasmo, Sari/Miklóssy, Katalin (eds.): Reassessing Cold War Europe, Routledge, London/New York 2011; Villaume, Poul/Westad, Odd Arne (eds.): Perforating the Iron Curtain: European Détente, Transatlantic Relations, and the Cold War, 1965-1985, Museum Tusculanum Press, Copenhagen 2010.

${ }^{87}$ Kansikas, Suvi: Socialist Countries Face the European Community: Soviet-Bloc Controversies over East-West Trade, Lang, Brussels 2014; Romano, Angela: From Détente in Europe to European Détente: How the West Shaped the Helsinki CSCE, Lang, Brussels 2009 and her forthcoming: The European Community and Eastern Europe in the Cold War: The EC's Ostpolitik and the Transformation of Intra-State Relations, Routledge, London/New York 2019.

${ }^{88}$ Also see Patel, Kiran Klaus/Weisbrode, Kenneth (eds.): European Integration and the Atlantic Community in the 1980s, Cambridge UP, Cambridge 2013.

89 Zaccaria, Benedetto: The EEC's Yugoslav Policy in Cold War Europe, 1968-1980, Palgrave Macmillan, London/New York 2016.
} 
lenging the conflict's pervading power. ${ }^{90}$ This article is not the space to discuss this debate in its own right. However, recent advances in European integration research underscore the role of regional and local dynamics beyond the superpower perspective; they also shed new light on the Cold War's end. Such findings thus help to add nuance to our understanding of the East-West conflict. They also show that international organizations along with transnational movements and flows were not completely controlled by it. In sum, recent advances in European integration history speak to much broader historiographical debates and might help to rejuvenate the debate about the Cold War and its limits.

The last point, on the rise of international organizations in 20th century Europe, is also supported by a co-edited volume on the history of international summitry from the 1970s to the 1990s. The approach of Emmanuel Mourlon-Druol and Federico Romero, the book's editors, is particularly insightful since it combines an analysis of European Councils with that of G7 meetings. Since both formats were only (fully) established in the 1970s as mechanisms to react to the seminal challenges of the time, this approach is highly useful. From the vantage point of European integration research, the volume is highly effective in contextualizing the rise of EU summitry; in fact, several of its chapters add further formats and forums into the mix, such as the OECD and GATT, in which Western governments bargained the various issues at stake. ${ }^{91}$

Peo Hansen and Stefan Jonsson pick up on another fascinating, even more global historical thread. Their book on Eurafrica scrutinizes the links between European integration and colonialism. To be sure, the topic is not quite as "neglected or ignored in scholarship" as the two authors argue-still, this important dimension of early efforts of European integration history is absent in textbook summaries of the topic as well as in public discourse, while there is a specialized literature that has dealt with the issue at stake extensively. The two Swedish scholars rightly argue that Africa was an integral part in blueprints for European integration during the interwar years. Also, the Schuman Declaration of 1950 and subsequent steps were imbued with late-colonial thinking. A long list of quotes from leading actors involved in European integration along with maps and other illustrations provide good evidence for this. The book, which benefits from the combination of Hansen's background in political science and Jonsson's in cultural theory, is more about plans than about practices, however. Moreover, "Eurafrica" has a proclivity to monocausal explanation that tends to view all of European integration through the lens of this link to colonialism. This bias is problematic, despite the book's many virtues. Still,

\footnotetext{
90 See as examples of texts that have already turned into classics of this genre Connelly, Matthew: Taking Off the Cold War Lens: Visions of North-South Conflict during the Algerian War for Independence, in: American Historical Review 105, 3 (2000), pp. 739-769; Iriye, Akira: Historicizing the Cold War, in: Immerman, Richard/Goedde, Petra (eds.): The Oxford Handbook of the Cold War, Oxford UP, Oxford u. a. 2013, pp. 15-31.

91 Mourlon-Druol, Emmanuel/Romero, Federico (eds.): International Summitry and Global Governance: The Rise of the G7 and the European Council, 1974-1991, Routledge, London/New York 2014.
} 
Hansen and Jonsson have produced a very useful piece of research which deserves a place on all reading lists on European integration history. ${ }^{92}$

To conclude: While the transatlantic dimension had been researched ever since the early days of EU historiography, recent advances have branched out to a whole host of world regions and developed innovative approaches to study them with. The increasing geographical spread reflects a growing awareness of the EC's global links, reflecting its late colonial origins and its increasing role as postwar decades progressed. The latter also held true because of the transformation of the international system and the rise of new actors, such as Japan, which the EC started to engage with. ${ }^{93}$ Conceptually, diplomatic history continues to play an important role, but so does the analysis of perceptions. Research is particularly strong where it combines voices from within the member states, transnational actors, and the other countries at stake, and where European integration under the banner of the predecessors of today's EU is contextualized with other forums and formats. Such work demonstrates that the EU often remained a subordinate player, but also that it was particularly the interaction with third parties that allowed it to rise to greater prominence in the course of the decades, sometimes reinforcing, sometimes qualifying the Cold War. Taken together, the field thus addresses key questions of today's international history, and its findings have a lot to offer for this broader conversation.

\section{Conclusion}

In sum, European integration research has long left its moorings in providing a useful past for a political project in our own times. While diplomatic history continues to play a prominent role, many other approaches have joined the conversation and thus broadened the scope and nuanced the findings in this field of enquiry. This also holds true due to the interdisciplinary nature of many projects, be it in dialogue with political science, legal studies, cultural anthropology or other fields. Such exchange is highly fruitful for many reasons, not least because it can help to address a fundamental challenge for all historians of the contemporary era: for most issues and questions, social scientists and others have already provided a lot of insights. ${ }^{94}$ Whereas older integration research tended to ignore such studies, insisting on superior insights thanks to freshly available archival evidence, a lot of the more recent

\footnotetext{
92 Hansen, Peo/Jonsson, Stefan: Eurafrica: The Untold History of European Integration and Colonialism, Bloomsbury, London/New York 2014, quote p. xiv; see for example also on this topic Dimier, Véronique: The Invention of a European Development Aid Bureaucracy: Recycling Empire, Palgrave Macmillan, Basingstoke/New York 2014; Rempe, Martin: Entwicklung im Konflikt. Die EWG und der Senegal, 1957-1975. Böhlau, Cologne 2012; Montarsolo, Yves: L'Eurafrique, contrepoint de l'idée d'Europe, Publications de l'Université de Provence, Aix-en-Provence 2010.

93 See, e.g., Frattolillo, Oliviero: Diplomacy in Japan-EU Relations: From the Cold War to the Post-Bipolar Era, Routledge, London 2013; Keck, Jörn/Vanoverbeke, Dimitri/Waldenberger, Franz (eds.): EU-Japan Relations, 1970-2012: From Confrontation to Global Partnership, Routledge, London/New York 2013.

94 On this issue and its challenges for historical research, see particularly Graf, Rüdiger/Priemel, Kim Christian: Zeitgeschichte in der Welt der Sozialwissenschaften, in: Vierteljahreshefte für Zeitgeschichte 59 (2011), pp. 479-508.
} 
research in integration history opts for a less naïve approach: a deep understanding of literature from adjacent disciplines, a selective adaptation of their theories and methods, and the aspiration to arrive at new empirical findings and claims inform the work, and sometimes even lead to systematic forms of interdisciplinary cooperation. This, as well as the many attempts to link European integration to broader processes in contemporary history, be it the rise of human rights, the new role of international organizations, or civic engagement, underscore the field's relevance for other historiographical debates. This also holds true because quite a few recent studies de-center or even seek to provincialize the EC/EU by inserting it into the broader realm of other international organizations in Europe's international history..$^{95}$ In some of this work, for instance by Warlouzet or, from a very different vantage point, by Domnitz, the EC/EU does not appear as the only or obvious European forum, and this approach helps to complicate the story of when, how-and whether-the EC/EU actually did acquire a particularly relevant role over time.

In sum, the borders of this field have become fuzzier, and one might ask what counts as a contribution to this field and what lies beyond it. This, however, is a positive development. The dialogue with historians specializing on other issues needs to be strengthened further, and recent advances in the field show that it has a lot to offer. In history in general, transnational approaches have gained momentum over the past two or three decades. Transnational historians, but for instance also economic historians and those interested in the history of production and consumption or questions of political representation, can hardly afford to further ignore the work on what is arguably the most extensive transnational collaboration under political auspices in contemporary history.

As an afterthought, it is interesting to reflect on the ways that research in this field is presented. During the first decades of research, scholars mostly resorted to their national publication cultures; the aforementioned European Union Liaison Committee of Historians, established in 1982, was among the first to foster an international dialogue with its multilingual monographs and, since 1995, its multilingual journal. Others have followed this lead, such as Studien zur Geschichte der Europäischen Integration with Franz Steiner Verlag (since 2009) which accepts texts either in French, German, or English and always adds extended summaries in the other two languages. These formats all continue to exist, but it is revealing that over the past ten years, quite a few scholars have chosen not to publish in their native language but in English-for instance Pasture from Belgium, Warlouzet from France, Romano from Italy, or Hansen and Jonsson from Sweden. It remains to be seen if this internationalization à l'anglaise, challenging the emphatically multilingual publication culture that had characterized the field before, will survive recent phenomena such

\footnotetext{
95 Patel, Kiran Klaus/Kaiser, Wolfram (eds.): Multiple Connections in European Cooperation: International Organizations, Policy Ideas, Practices and Transfers 1967-1992, in: European Review of History 24, 3 (2017) (special issue); Kaiser, Wolfram/Schot, Johan: Writing the Rules for Europe: Experts, Cartels, and International Organizations, Palgrave Macmillan, Houndmills 2014; see also Patel, Kiran Klaus: Provincialising European Union: Co-operation and Integration in Europe in a Historical Perspective, in: Contemporary European History 22 (2013), pp. 649-673; Patel, Kiran Klaus, Projekt Europa. Eine kritische Geschichte, Beck, Munich 2018.
} 
as the rise of neo-nationalism, also in academia, and Brexit, and how the future trajectory of European integration will impact on the research in this field.

\section{Select bibliography}

- Clemens, Gabriele (ed.): Werben für Europa. Die mediale Konstruktion europäischer Identität durch Europafilme, 620 pages, Schöningh, Paderborn 2016.

- Hansen, Peo/Jonsson, Stefan: Eurafrica: The Untold History of European Integration and Colonialism, 344 pages, Bloomsbury, London/New York 2014.

- James, Harold: Making the European Monetary Union, 592 pages, Harvard UP, Cambridge, MA/London 2012.

- Loth, Wilfried: Building Europe: A History of European Unification, 485 pages, De Gruyter, Berlin u. a. 2015.

- Marung, Steffi: Die wandernde Grenze. Die EU, Polen und der Wandel politischer Räume, 1990-2010, 400 pages, Vandenhoeck \& Ruprecht, Göttingen 2013.

- Vauchez, Antoine: Brokering Europe: Euro-Lawyers and the Making of a Transnational Polity, 278 pages, Cambridge UP, Cambridge 2015.

- Warlouzet, Laurent: Governing Europe in a Globalizing World: Neoliberalism and its Alternatives Following the 1973 Oil Crisis, 274 pages, Routledge, London/New York 2018.

Open Access This article is distributed under the terms of the Creative Commons Attribution 4.0 International License (http://creativecommons.org/licenses/by/4.0/), which permits unrestricted use, distribution, and reproduction in any medium, provided you give appropriate credit to the original author(s) and the source, provide a link to the Creative Commons license, and indicate if changes were made. 